\title{
Evaluation of the Patients with Abnormal Uterine Bleeding Based on PALM-COEIN Classification
}

\section{Anormal Uterin Kanama ile Bașvuran Kadınların PALM-COEIN Klasifikasyonuna göre Değerlendirilmesi}

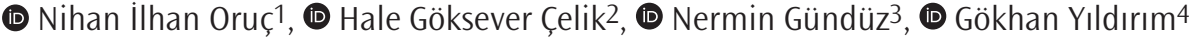 \\ 1istanbul Bahçelievler General Hospital, Clinic of Obstetrics and Gynecology, İstanbul, Turkey \\ 2University of Health Sciences, Kanuni Sultan Süleyman Training and Research Hospital, Clinic of Obstetrics and Gynecology, İstanbul, Turkey \\ 3University of Health Sciences, Kanuni Sultan Suleyman Training and Research Hospital, Clinic of Pathology, Istanbul, Turkey \\ ${ }^{4}$ istanbul Medipol University Faculty of Medicine, Department of Obstetrics and Gynecology, ístanbul, Turkey
}

\begin{abstract}
Introduction: The PALM-COEIN classification, described and recently published by the International Federation of Gynecology and Obstetrics (FIGO), allows epidemiological information in women with abnormal uterine bleeding, as well as thorough assessment and proper management. We aimed to classify patients who applied to our gynecology outpatient clinic with abnormal uterine bleeding according to PALMCOEIN classification.

Methods: Our prospective observational study was conducted with non-pregnant women aged $15-45$ years who were admitted to the gynecology outpatient clinic between June 2017 and March 2018. Patients were grouped according to PALM-COEIN classification by anamnesis, transvaginal ultrasonography, laboratory tests, hysteroscopy and pathology results.

Results: The cases were classified into two groups as structural causes (PALM) and non-structural causes (COEIN). There were 199 cases (49.4\%) in the PALM group and 204 cases (50.6\%) in the COEIN group. In the PALM group, polyp was found as the most common cause of abnormal uterine bleeding in 79 cases (19.6\%). The most common cause in COEIN group iatrogenic was with 80 cases (19.9\%). There was a statistically significant difference between the two groups regarding age, body mass index and the need for surgery.
\end{abstract}

Conclusion: The diagnosis and management of abnormal uterine bleeding becomes easier and more objective with the use of PALM-COEIN system.

Keywords: Abnormal uterine bleeding; PALM-COEIN, FIGO classification, terminology

\section{öz}

Amaç: Uluslararası Jinekoloji ve Obstetri Federasyonu tarafından tanımlanan ve yakın zamanda kullanıma sunulmuş olan PALM-COEIN sınıflaması, anormal üterin kanaması olan kadınlarda epidemiyolojik bilgi sağlamasının yanısıra hastaların ayrıntılı değerlendirilmesine ve doğru yönetimine olanak sağlamaktadır. Amacımız, anormal üterin kanama ile jinekoloji polikliniğimize başvuran kadınların PALM-COEiN sınıflamasına göre sınıflandırılmasıdır.

Yöntemler: Çalıșmamız, Haziran 2017-Mart 2018 tarihleri arasında jinekoloji polikliniklerine anormal üterin kanama şikayetiyle başvuran 15-45 yaş arası gebe olmayan kadınlar arasında prospektif olarak yapıldı. Hastalar anamnez, transvajinal ultrason, laboratuvar tetkikleri, histeroskopi ve patoloji sonuçlarıyla değerlendirilerek PALM-COEiN sınıflandırmasına göre gruplandırıldı.

Bulgular: Olgular yapısal nedenler (PALM) ve yapısal olmayan nedenler (COEIN) diye sınıflandırıldığında oranların sırasıyla $\% 49,4$ ve \%50,6 olduğu görüldü. PALM grubunda 199 olgu, COEiN grubunda ise 204 olgu bulundu. PALM grubunda 79 olguyla en sık neden AUK-P (\%19.6) idi. Toplam 204 olgunun olduğu COEIN grubunda en sık neden 80 olguyla ve $\% 19.9$ oranla AUK-I bulundu. İi grup arasında (PALM ve COEIN), abortus, küretaj, ektopik gebelik, sezaryen öyküsü, komorbidite, kanser öyküsü, ailede kanser öyküsü, başvuru yakınması, smear, polikistik over görünümü, adneksiyel patoloji varlığı ve boyutu açısından istatistiksel anlamlı fark bulunmadı.

Sonuç: Anormal üterin kanamanın tanısı ve yönetimi, PALMCOEIN sınıflamasının kullanılmasıyla daha kolay ve objektif hale gelmiștir.

Anahtar Kelimeler: Anormal üterin kanama, PALM-COEIN, FiGO sınıflaması, terminoloji 


\section{Introduction}

Abnormal uterine bleeding (AUB) is a common symptom in gynecology practice. Approximately $10-35 \%$ of women have experienced AUB at least once in their lifetime (1). In the United States, the prevalence of abnormal uterine bleeding is 53 in 1000 between 18-50 years of age, with a mean menarche age of 12 years and a mean menopause of 51 years $(2,3)$. AUB is an important health problem for women in reproductive age who need to admit to a hospital and it has consequences such as blood loss, reduced sexual and reproductive health, and increased health care use and expenditure (4). It is responsible for $25 \%$ of gynecologic operations, $30 \%$ of all outpatient applications and $70 \%$ of outpatient applications among perimenopausal and postmenopausal patients (5).

The PALM-COEIN classification, that is described and recently published by the International Federation of Gynecology and Obstetrics (FIGO), allows epidemiological information in women with abnormal uterine bleeding, as well as thorough assessment and proper management of patients. This new classification introduces a new terminology system as well as etiology. According to the new terminology, the use of the terms "severe menstrual bleeding" instead of "menorrhagia" and "intermenstrual hemorrhage" instead of "metrorrhagia" has been proposed. The term "dysfunctional uterine bleeding" is not used in the new terminology.

In the PALM-COEIN classification, the PALM group includes polyps, adenomyosis, leiomyoma and malignancy as structural causes, while the COEIN group includes non-structural causes such as coagulopathy, ovarian dysfunction, endometrial, iatrogenic and unclassifiable (6).

In this study, we aimed to classify non-pregnant women aged 15-45 years who were admitted to the gynecology outpatient clinic with the complaint of AUB between June 2017 and March 2018. We also aimed to evaluate the clinical and demographic characteristics of these patients, and to shed light on the diagnosis and treatment algorithm for this condition affecting many women.

\section{Methods}

This study was conducted prospectively in non-pregnant women aged 15-45 years who were admitted to the gynecology outpatient clinic between June 2017 and March 2018. University of Health Sciences, Kanuni Sultan Süleyman Training and Research Hospital Local Ethics Committee approved the study (KAEK/2018.4.12). All procedures performed in the study were in accordance with the ethical standards of the institutional research committee and with the 1964 Helsinki declaration and its later amendments or comparable ethical standards. Informed consent was obtained from all patients, allowing the use of their blinded clinical data for research purposes.

General physical and pelvic examinations were performed after all complaints were received and detailed anamnesis was taken. Age, obstetric history, bleeding pattern, drug use, contraceptive method, and presence of systemic disease, cancer and family history were questioned. In sexually active patients, transvaginal ultrasonography (TV-US) was performed in the dorsal lithotomy position after urination. Sexually inactive patients were evaluated by abdominal ultrasonography. Cervix, cervical canal, uterus, endometrial cavity and ovaries were evaluated, and abnormal findings (e.g. myoma, polyps, adnexal mass, etc.) were recorded. Endometrial thickness measurements were made by measuring the largest anterior-posterior diameter on the long axis. Patients with abnormal masses in the uterine cavity were evaluated by office hysteroscopy. Endometrial biopsy was performed in septic intervention unit of our hospital. Smears, endometrial biopsies and histopathologic examination of the specimens were evaluated in pathology laboratory of our hospital. All patients were requested to have laboratory tests including complete blood count, prothrombin time (PT), activated partial prothrombin time (aPTT), pregnancy test (beta-HCG), free T3 (fT3), free T4 (fT4) and thyroid stimulating hormone (TSH).

Exclusion criteria were as follows: patients with positive pregnancy test, postmenopausal bleeding, acute genital tract infection, and patients who did not want to participate in the study.

The polyps constituted the AUB-P group, whereas malignancy and hyperplasia constituted the AUB-M group. The proliferative endometrium (AUB-O group) and the secretory endometrium (AUB-E group) were diagnosed with endometrial biopsy. Adenomyosis (AUB-A group) and leiomyomas (AUB-L group) were diagnosed by ultrasonography. Anamnesis and laboratory tests were used for diagnosing AUB-C and AUB-I groups. The diagnosis of isthmocele (AUB-N group) was made by ultrasonography and office hysteroscopy.

Endometrial biopsy results were divided into 11 groups as benign endometrial fragments, typical and atypical simple endometrial hyperplasia, typical and atypical complex endometrial hyperplasia, proliferative endometrium, endometrial polyp, chronic endometritis, secretory endometrium, endometrium adenocarcinoma and cervical carcinoma.

\section{Statistical Analysis}

In power analysis with $\mathrm{G}$ * Power 3.1 program with an effect size of 0.5 and level of significance of $5 \%$, the number of samples required for $80 \%$ power was found as 385 . Statistical analyses were performed using Statistical Package for the Social Sciences (SPSS Inc.; Chicago, IL, USA) for Windows version 22.0. $p<0.05$ was considered statistically significant. Risk ratio, odds ratio (OR) and 95\% confidence interval were calculated. The difference between mean values and characteristics between the groups were analyzed with independent samples t-test and chi-square test. Means were presented with standard deviation (SD).

\section{Results}

A total of 403 women aged $15-45$ years with abnormal uterine bleeding were included in this prospective observational study. Demographic and clinical findings of all participants were summarized and presented in Table 1.

According to the PALM-COEIN classification developed by FIGO in 2011, 199 cases (49.4\%) with structural causes were included in the PALM group and 204 cases (50.6\%) with non- structural causes were included in the COEIN group (Table 2). The most common etiologic cause in the COEIN group was AUB-I with 80 cases (19.9\%) and was AUB-P with 79 cases $(19.6 \%)$ in the PALM group. Patients using selective serotonin reuptake inhibitors (SSRIS), warfarin, and the most preferred intrauterine device 
(IUD) in our population, progesterone IUD users were grouped as AUB-I. In this group, von Willebrand disease was present in two cases and immune thrombocytopenic purpura was present in two cases. Fifteen patients with no etiological causes and two isthmocele cases (4.2\%) were evaluated in the AUB-N group (Figure 1 showing the distribution of patients based on PALM-COEIN classification).

When we compared the patients in the structural (PALM) and nonstructural (COEIN) groups, there was a statistically significant difference between the two groups regarding age and body mass index (BMI) ( $p$ $<0.001$ ). The relationship between parity and etiology was not statistically significant in both structural and non-structural reasons (Table 3). When

\begin{tabular}{|c|c|}
\hline Characteristics & Mean \pm SD or number $(\%)$ \\
\hline Age (years) & $39.7 \pm 5.3$ (range: $15-45)$ \\
\hline BMI $\left(\mathrm{kg} / \mathrm{m}^{2}\right)$ & $29.7 \pm 4.8$ (range: $19-44$ ) \\
\hline \multicolumn{2}{|l|}{ Parity } \\
\hline 0 & $22(5.5)$ \\
\hline$\geq 1$ & $382(94.5)$ \\
\hline \multicolumn{2}{|l|}{ Abortus } \\
\hline 0 & $276(68.5)$ \\
\hline$\geq 1$ & $127(31.5)$ \\
\hline \multicolumn{2}{|l|}{ Curettage } \\
\hline 0 & $343(85.1)$ \\
\hline$\geq 1$ & $60(14.9)$ \\
\hline \multicolumn{2}{|l|}{ Ectopic pregnancy } \\
\hline 0 & $392(97.3)$ \\
\hline$\geq 1$ & $11(2.7)$ \\
\hline \multicolumn{2}{|l|}{ History of cesarean section } \\
\hline Absent & $263(65.3)$ \\
\hline Present & $140(34.7)$ \\
\hline \multicolumn{2}{|l|}{ Comorbidity } \\
\hline Absent & $302(74.9)$ \\
\hline Present & $101(25.1)$ \\
\hline \multicolumn{2}{|l|}{ Cancer history } \\
\hline Absent & $397(98.5)$ \\
\hline Present & $6(1.5)$ \\
\hline \multicolumn{2}{|l|}{ Contraceptive method } \\
\hline Absent & $242(60)$ \\
\hline Bilateral tubal ligation & $37(9.2)$ \\
\hline Intrauterine device & $60(14.9)$ \\
\hline Intrauterine device with progesterone & $45(11.2)$ \\
\hline Condom & $3(0.7)$ \\
\hline Oral contraceptive & $14(3.5)$ \\
\hline Injectable contraception & $1(0.2)$ \\
\hline Minipill & $1(0.2)$ \\
\hline \multicolumn{2}{|l|}{ Complaint } \\
\hline Menometrorrhagia & $319(79.2)$ \\
\hline Menorrhagia & $63(15.6)$ \\
\hline Metrorrhagia & $21(5.2)$ \\
\hline
\end{tabular}

the cases were evaluated according to the contraceptive methods, it was seen that the use of contraceptive method, especially IUD (70\%) and oral contraceptive (78.6\%), was higher in the COEIN group $(p=0.006)$.

When the rates of surgery were evaluated during the study period, the rate of surgery in the PALM group was significantly higher than the COEIN group $(p<0.001)$ (Table 3$)$.

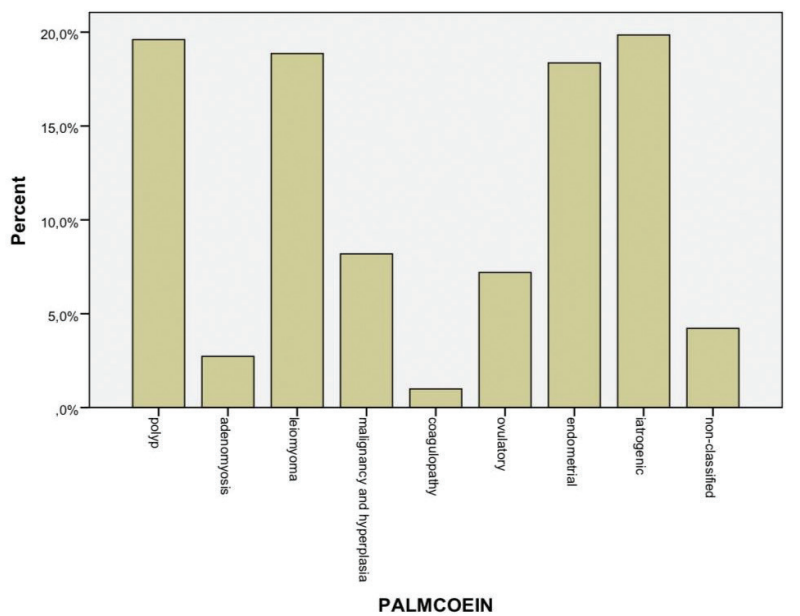

Figure 1. The figure showing the distribution of the patients based on PALM-COEIN classification

Table 2. The distribution of the patients based on PALM-COEIN classification

\begin{tabular}{|l|l|l|}
\hline Group & Number, \% \\
\hline Polyp & $79(19.6)$ & \\
\hline Adenomyosis & $11(2.7)$ & PALM ( $=199,49.4 \%)$ \\
\hline Leiomyoma & $76(18.9)$ & \\
\hline Malignancy and hyperplasia & $33(8.2)$ & \\
\hline Coagulopathy & $4(1.0)$ & COEIN $(n=204,50.6 \%)$ \\
\hline Ovulatory & $29(7.2)$ & \\
\hline Endometrial & $74(18.4)$ & \\
\hline latrogenic & $80(19.9)$ & \\
\hline Non-classified & $17(4.2)$ & \\
\hline
\end{tabular}

Table 3. Comparison of the patients in the structural and nonstructural groups

\begin{tabular}{|c|c|c|c|}
\hline Characteristics & PALM group & COEIN group & p \\
\hline Age (years) & $40.7 \pm 4.4$ & $38.8 \pm 5.8$ & $<0.001$ \\
\hline BMI $\left(\mathrm{kg} / \mathrm{m}^{2}\right)$ & $30.6 \pm 4.6$ & $28.9 \pm 4.9$ & $<0.001$ \\
\hline \multicolumn{4}{|l|}{ Parity } \\
\hline 0 & $14(63.6)$ & $8(36.4)$ & \multirow{2}{*}{ Not significant } \\
\hline$\geq 1$ & $185(48.6)$ & $196(51.4)$ & \\
\hline \multicolumn{4}{|l|}{ Surgery } \\
\hline None & $164(45.3)$ & $198(54.7)$ & \multirow{5}{*}{$<0.001$} \\
\hline Hysterectomy & $21(100)$ & 0 & \\
\hline Myomectomy & $5(83.3)$ & $1(16.7)$ & \\
\hline Operative hysteroscopy & $9(69.2)$ & $4(30.8)$ & \\
\hline Ovarian surgery & 0 & $1(100)$ & \\
\hline
\end{tabular}

PALM: structural group, COEIN: non-structural group, BMI: body mass index 


\section{Discussion}

AUB is an important public health problem that occurs in $10-35 \%$ of women at least once in their lifetime (5). Many studies have been conducted on this situation, which affects social life, sexual health and mental status of women. The use of the objective PALM-COEIN system will provide a faster and more effective planning of diagnosis and treatment, rather than the classical terminology system that is difficult to use and inadequate to determine the etiology, which can vary relatively to the perception of the patient and the clinician. We grouped 403 patients aged 15-45 years who were admitted to Gynecology outpatient clinic with abnormal uterine bleeding between June 2017 and March 2018 according to PALM-COEIN classification.

When our cases were divided into two groups as structural causes (PALM) and non-structural causes (COEIN), the rates were $49.4 \%$ and $50.6 \%$, respectively. In a similar study conducted by Mishra and Sultan (7) in 236 cases, the rate of PALM group was $50.2 \%$ and the rate of COEIN group was $49.8 \%$, which is similar to our results.

The most frequent cause of all etiologic factors in our study was iatrogenic causes, known as AUB-I in the COEIN group (19.9\%). The widespread use of copper IUD as a contraceptive method in our society seems to increase this rate. Copper IUD, first used in the early 1970s, is a highly reliable and safe form of contraception currently used by $15.5 \%$ of women in reproductive age and $7.7 \%$ of American women using contraception worldwide (8). A total of 60 patients (14.9\%) preferred contraception with copper IUD. Andrade and Pizarro Orchard (9) found that the average amount of blood loss per woman per cycle increases from $32 \mathrm{~mL}$ to $37-40 \mathrm{ml}$ with copper IUD.

In our study, 45 patients were found to prefer hormone-releasing IUD either for contraception or for management of AUB. Many women experience unexpected vaginal spotting/bleeding during the first 3-6 months of use of this hormone-releasing IUD. Backman et al. (10) conducted a nationwide study of 17.360 women in Finland and found that the most common reason for discontinuing this hormonereleasing IUD was unexpected, irregular uterine bleeding (10). In a study conducted in England, 10\% of new users of this IUD discontinued the method at the end of the first year due to irregular bleeding. The rate of discontinuation due to AUB was $16.7 \%$ within 5 years (11).

latrogenic causes include the use of SSRIs that cause AUB that affects dopamine metabolism. In a case-control study of SSRIs users, the authors found that the use of SSRIs at moderate and high doses increased AUB (12). Another mechanism behind these effects is that SSRIs limit the uptake of blood serotonin with platelets. Since platelets cannot synthesize serotonin, this causes a decrease in serotonin concentration in platelets and decreased serotonin amount in platelets increases the risk of abnormal bleeding (13). latrogenic agents also include anticoagulants such as warfarin. Warfarin blocks the gammacarboxylation of the terminal regions of vitamin K-dependent proteins by preventing the vitamin $\mathrm{K}$ from returning to the epoxide state of vitamin $\mathrm{K}$, resulting in a decrease in clotting factors II, VII, IX and X (14).

According to the results of our study, AUB-P was found as the second most common cause (19.6\%) at almost the same rate with AUB-I. This rate was found to be $21 \%$ in our study, similar to the study conducted by
Toz et al. (15) that evaluated the pathological specimens of patients aged 18-55 years who had hysterectomy, myomectomy and polypectomy due to AUB. This rate was $15 \%$ in another study including 176 patients aged 41-50 years (16).

In our study, the rate of AUB-L subgroup in the PALM group was 38\%. In the study of Arnold and Saravanan (17), this rate was found $40 \%$, similar to our study. Especially submucosal leiomyomas are thought to contribute to the formation of AUB. However, intramural fibroids may cause AUB by altering the muscular contraction of the uterus and pressing the veins in the uterine wall (18).

The AUB-E group includes the secretory endometrium and chronic endometritis. Seventy-four cases (18.4\%) were found in the AUB-E group in our population. In the study conducted by Talukdar and Mahela (18) correlating hysterectomy materials, endometrial biopsy and ultrasound, this rate was similar to our study with $19.4 \%$. Singh et al. (19) performed a study in 550 samples and according to their findings; this rate was different from our study with $24 \%$.

The fifth common cause of AUB was AUB-M (malignancy and hyperplasia) in our study. The AUB-M subgroup was arranged according to endometrial biopsy results; including simple endometrial hyperplasia with or without atypia, complex endometrial hyperplasia with or without atypia, endometrial adenocarcinoma and cervical cancer. Although there was no consensus in the studies on this subject, some researchers evaluated the atypia and hyperplasia in the AUB-E group. However most investigators chose to consider the atypia and hyperplasia in the AUB-M group. In a similar study by Mishra and Sultan (7), all types of hyperplasia were grouped in the AUB-M group and this rate was found to be $10.2 \%$ (7). Toz et al. (15) performed a study on the hysterectomy, myomectomy and polypectomy materials of 471 AUB patients aged 1855 years and this rate was found to be $11 \%$ (17).

In our study, two patients were diagnosed with endometrial cancer. The rate of endometrial cancer in all cases was $0.5 \%$. In the literature, this rate varies between $0.2 \%$ and $1.4 \%(15,17)$.

The sixth most common cause in our study was the AUB-O group with 29 cases and $7.2 \%$ rate. This group includes patients with unregulated proliferative endometrium as a result of endometrial biopsy and ultrasonographic polycystic ovary appearance. Mishra and Sultan (7). reported this rate as $9 \%$ in their study (7). In the study of Toz et al. (15), this rate was found to be $2.7 \%$. The reason for this difference is thought that their study was based on the surgery specimens. Because the main treatment of ovulatory dysfunction is medical treatment, there may be missing cases (17).

The seventh most common cause of AUB according to our study was AUB-A. In clinical and histopathological studies, the rate of AUB-A was similarly $3.8 \%(7)$. In the study of Toz et al. (15), this rate was found to be $38 \%$, which is quite different from our study (17). The reason for this difference is the difficulty in diagnosing adenomyosis by imaging methods and endometrial biopsy, thus the definitive diagnosis is made with histopathological examinations.

The least common cause of AUB was found to be AUB-C group. Von Willebrand disease was present in two cases and immune thrombocytopenic purpura was present in two cases. According to 
another study in 200 cases, this rate was 2\% (20). This rate was found to be $0 \%$ in the studies of Arnold and Saravanan (17) and Mishra and Sultan (7) (16). The reason for this difference is that multidisciplinary approach is needed for definitive diagnosis of coagulopathies.

A total of 17 cases (4.2\%) were classified in the AUB-N group. These cases were not considered in any category or no etiologic cause could be detected in this group.

The American Society of Obstetrics and Gynecology (ACOG) asserted that medical treatment is the first-line treatment in acute AUB in women without systemic hematological disorders. Surgical treatment should be performed considering the stability of the patients, the severity of bleeding and underlying disease. It should be preferred in cases where medical treatment is contraindicated and there is no response to medical treatment (21). Medical treatments include hormonal and non-hormonal options, and the most effective ones in reducing AUB are progesterone IUDs, tranexamic acid and long-term oral progesterone (22). Surgical treatment options range from simple procedures to comprehensive surgery. As a matter of fact, in our study, the rate of surgery in the PALM group was found to be significantly higher than the COEIN group.

\section{Conclusion}

As a conclusion, the use of the objective PALM-COEIN system enables a faster and more efficient planning of diagnosis and treatment rather than the classical terminology system based on the perception of the patient and clinician, which is relatively difficult to use and difficult to determine the reason of AUB with.

\section{Acknowledgements}

The authors would like to thank the participants of this study.

Ethics Committee Approval: University of Health Sciences, Kanuni Sultan Süleyman Training and Research Hospital Local Ethics Committee approved the study (KAEK/2018.4.12).

Informed Consent: Informed consent was obtained from all patients.

Peer-review: Externally peer-reviewed.

Author Contributions: Surgical and Medical Practices - N.I.O., H.G.C., G.Y.; Concept - N.I.O., H.G.C., N.G., G.Y.; Design - H.G.C., N.G., G.Y.; Data Collection and/ or Processing - N.I.O., N.G.; Analysis and/or Interpretation - H.G.C.., G.Y.; Literature Search - N.I.O., H.G.Ç.; Writing Manuscript N.I.O., H.G.C..

Conflict of Interest: The authors declare that they do not have any conflict of interest in regard to this article.

Financial Disclosure: The authors declared that this study received no financial support.

\section{References}

1. Pai M, Chan A, Barr R. How I manage heavy menstrual bleeding. Br J Haematol 2013; 162: 721-9.

2. Ferenczy A, Bertrand G, Gelfand MM. Proliferation kinetics of human endometrium during the normal menstrual cycle. Am J Obstet Gynecol 1979; 133: 859-67.
3. Anderson SE, Must A. Interpreting the continued decline in the average age at menarche: results from two nationally representative surveys of U.S. girls studied 10 years apart. J Pediatr 2005; 147: 753-60.

4. Deneris A. PALM-COEIN Nomenclature for Abnormal Uterine Bleeding. J Midwifery Womens Health 2016; 61: 376-9.

5. Matthews ML. Abnormal uterine bleeding in reproductive-aged women. Obstet Gynecol Clin North Am 2015; 42: 103-15.

6. Munro MG, Critchley HO, Fraser IS. The FIGO classification of causes of abnormal uterine bleeding: Malcolm G. Munro, Hilary O.D. Crithcley, Ian S. Fraser, for the FIGO Working Group on Menstrual Disorders. Int J Gynaecol Obstet 2011; 113: 1-2.

7. Mishra D, Sultan S. FIGO's PALM-COEIN Classification of abnormal uterine bleeding: A clinico-histopathological correlation in indian setting. J Obstet Gynaecol India 2017; 67: 119-25.

8. Finer LB, Jerman J, Kavanaugh ML. Changes in use of long-acting contraceptive methods in the United States, 2007-2009. Fertil Steril 2012; 98: 893-7.

9. Andrade AT, Pizarro Orchard E. Quantitative studies on menstrual blood loss in IUD users. Contraception 1987; 36: 129-44.

10. Backman T, Huhtala S, Blom T, Luoto R, Rauramo I, Koskenvuo M. Length of use and symptoms associated with premature removal of the levonorgestrel intrauterine system: a nation-wide study of 17,360 users. BJOG 2000; 107: 335-9.

11. Cox M, Tripp J, Blacksell S. Clinical performance of the levonorgestrel intrauterine system in routine use by the UK Family Planning and Reproductive Health Research Network: 5-year report. J Fam Plann Reprod Health Care 2002; 28: 73-7.

12. Scott. Users of SSRIs face risk of abnormal bleeding. BMJ 2004; 329: 1258.

13. Skop BP, Brown TM. Potential vascular and bleeding complications of treatment with selective serotonin reuptake inhibitors. Psychosomatics 1996; 37: $12-6$.

14. Kayser SR. Practical challenges in the management of oral anticoagulation. Prog Cardiovasc Nurs 2005; 20: 80-5.

15. Toz E, Sanci M, Ozcan A, Beyan E, Inan AH. Comparison of classic terminology with the FIGO PALM-COEIN system for classification of the underlying causes of abnormal uterine bleeding. Int J Gynaecol Obstet 2016; 133: 325-8.

16. Parker WH. Etiology, symptomatology, and diagnosis of uterine myomas. Fertil Steril 2007; 87: 725-36.

17. Arnold JAP, Saravanan S. A two year clinicopathological study of non-gravid women with abnormal uterine bleeding in a rural tertiary care centre in Tamilnadu: in concurrence with the Figo recommendations. J of Evolution of Med Dent Sci 2015; 63: 10990-11001.

18. Talukdar B, Mahela S. Abnormal uterine bleeding in perimenopausal women: Correlation with sonographic findings and histopathological examination of hysterectomy specimens. J Midlife Health 2016; 7: 73-7.

19. Singh P, Singh P, Chaurasia A, Dhingra V, Misra V. Expression of ER $\alpha$ and PR in Various Morphological Patterns of Abnormal Uterine Bleeding-Endometrial causes in Reproductive Age Group. J Clin Diagn Res 2016; 10: ECo6-9.

20. Shubham D, Kawthalkar AS. Critical evaluation of the PALM-COEIN classification system among women with abnormal uterine bleeding in lowresource settings. Intern J Gynaecol Obstet 2018; 141: 217-22.

21. American College of Obstetricians Gynecologists. ACOG committee opinion no. 557: management of acute abnormal uterine bleeding in nonpregnant reproductive-aged women. Obstet Gynecol 2013; 121: 891-6.

22. Bitzer J, Heikinheimo O, Nelson AL, Calaf-Alsina J, Fraser IS. Medical Management of Heavy Menstrual Bleeding: a comprehensive review of the literature. Obstet Gynecol Surv 2015; 70: 115-30. 